\title{
CLTシェルを構成する連結要素の位相構造計画手法の提案 TOPOLOGY FINDING METHOD OF LINK ELEMENTS FOR CLT SHELLS
}

\author{
野田 賢*1, 木 村 俊明*2 \\ Ken NODA and Toshiaki KIMURA
}

\begin{abstract}
This paper presents an optimization method of the joint arrangement for shell structures composed of CLT panels. The joining system is modeled as link elements with multidirectional stiffness. Their stiffnesses are calculated by multiplying the weight parameters defined as the design variables to the original stiffnesses. Furthermore, the joint arrangement is controlled by multiplying a power-law function to design variables. An optimization problem is formulated to minimize the strain energy. The effectiveness of the proposed method is shown through numerical examples. It is confirmed that the joint arrangement in each direction is optimized corresponding to the stress state.
\end{abstract}

Keywords: CLT shell, link element, topology optimization, joint stiffness, strain energy CLT シェル，連結要素，位相最適化，接合部岡性，ひずみエネルギー

\section{1. 序}

直交集成板（以下 CLT）は，ラミナを幅方向に並心゙，纎維方向が 直交するように積層接着された板状の木質系材料を指す。2016 年の 基準強度の告示化，一般的な設計法に関する技術的基準 1)の整備に 伴い，CLT を構造材料として採用することが容易になった。

CLT の床版を設計する場合, 一般的には二辺単純支持として強軸 方向（最外層ラミナの繊維方向）に応力伝達させる。積層板である ことを踏まえれば，二方向に応力伝達させることも可能であるが， CLT の製作・運搬上の寸法限界を超える場合は, 複数のパネルを適 切に連結する必要が生じる。また，平板の場合は，鉛直荷重に対し て面外力（曲げモーメント, 面外せん断力）を伝達できる接合具に より連結しなければならない。シェル構造のような立体架構となれ ば，さらに面内力（膜力, 面内せん断力）にも配慮する必要が生じ る。CLT を用いた二方向版や立体架構の設計法は十分に確立してい るとは言い難く, 個々の構造物に応じて研究開発されている事例が 多い。村上ら ${ }^{2,3}$ は GIR により幅方向を接合し, 板厚方向に 2 つの CLT パネルを直交積層して一体化させた二方向版を提案し, 数值解 析のモデル化と設計法について検討している。黒岩ら ${ }^{4}$ は千切りや 雇い実を用いた䈈合接合による単スパンの円筒シェルを計画し，シ ヨートシェルのユニットを並べた架構を実現している。Robeller ら 5)は，六角形の CLT パネルを䈟合と斜め打ちした木栓ダボで連結し たドーム構造を実現している。第一筆者は, CLT パネルを円弧状に 並べ, 複数の接合部で連結したシェル構造（以下, CLT シェル, 図 1）を提案した ${ }^{6)}$ ここでは, 必要な接合部剛性として, 軸剛性, 面 内せん断剛性, 面外せん断剛性および曲げ剛性を示し, 数值解析を
用いた検討結果を通して CLT シェルが実現可能な構造形式である こと, 設計する際は剛性に応じた複数種類の接合具を適切に選択す る必要があることを示している。

CLT シェルは構造要素 (CLT パネル)および連結要素(接合具群) で構成され，力学性状がそれらの結合関係（以下，位相構造）に依 存する離散型空間構造 7に分類することができる。CLT シェルにお いて，連結要素の合理的な位相構造を計画するためには，設計者は 連続体構造とは異なる力の流れを意識し，相互に影響しあう連結要 素の配置や剛性等を調整しながらシェル全体の応力状況を確認する 必要がある。このような複雑な問題に対して, 構造最適化を行い, 反復的な作業を計算機で処理出来れば，設計業務の効率化に有用で あると考えられる。

構造最適化の一つに位相最適化がある。Bendsøe らが提案した均 質化法 ${ }^{10)}$ は連続体を構成する微視構造の孔の大きさを最適化し, 構 造物の位相を求める手法である。藤井ら ${ }^{11)}$ は均質化法を用いてコン プライアント・メカニズムの位相最適化をしている。微視構造のト ポロジーを制御し, 複合材料で構成された連続体の構造性能を最適 化した事例もある ${ }^{12)}$ 。位相最適化をトラス構造や骨組構造のような 離散型構造へ応用した事例も数多く確認できる。Ohsaki 8 らは応力 密度法を用いてトラス構造の形状と位相を同時に最適化している。 木村ら 9)は鋼構造骨組の柱，梁およびブレースの断面の他，ブレー スの配置を同時に求めている。本研究で対象と寸る CLT シェルの ような木質構造において, 剛接合の実現は難しく，接合部の剛性を 適切に評価する必要がある。鋼構造骨組で接合部剛性に着目した事 例はいくつか確認できる。松本ら ${ }^{13)}$ は半剛接合された鋼構造骨組の
*1 金箱構造設計事務所 修士 (工学)

*2 名古屋市立大学大学院芸術工学研究科 講師·博士 (工学)
Kanebako Structural Engineers, M.Eng.

Lect., Graduate School of Design and Architecture, Nagoya City Univ., Dr.Eng. 
最適設計を行っている。Hagishita ら ${ }^{14)}$ は半剛接骨組のブレース配 置を最適化している。福島ら ${ }^{15)}$ は接合部剛性を考慮した木質構造の 単層ラチスシェルの形状最適化を行っているが, 接合部剛性を評価 して木質空間構造を最適化した研究は筆者の知る限り極めて少ない。

本論文は, CLT シェルを対象とし, 位相最適化を用いてパネル同 士を連結する接合具の構成を求める方法を提案する。まず, 接合具 の仕様に基づき, 軸方向剛性, 面内・面外せん断剛性および面外曲 げ剛性（回転剛性）で構成される連結要素を定義する（図 2)。これ らの剛性を既存の設計式や実験結果を基にば叔要素で評価する。次 に, 連結要素の重み付けパラメータを設計変数として, 外力仕事と 等価であるひずみエネルギーを目的関数, 連結要素数の上限を制約 条件とする最適化問題を定式化する。数值解析例では円筒形状の CLT シェルに対して最適化を行い, 得られた解について力学的特性 を考察する。

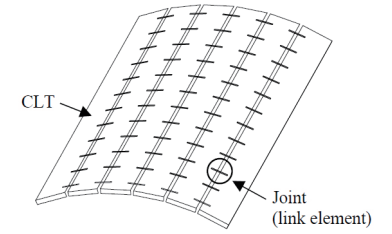

Fig. 1 Concept of CLT shell.

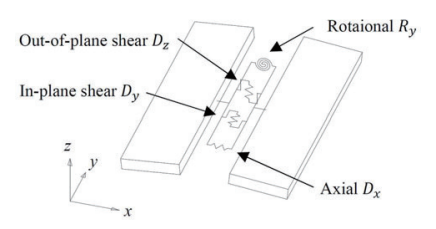

Fig. 2 Concept of link element.
2. CLT シェル

2. 1 . 概要

$L_{X} \times L_{Y}=8 \mathrm{~m} \times 8 \mathrm{~m}$ の矩形平面で, ライズ ${ }_{h}=1 \mathrm{~m}$ の円筒形状を持 つLT シェルを最適化対象と寸る。以後, $X$ 方向をアーチ方向, $Y$ 方向を母線方向と呼ぶ。例えば， 8 枚の CLT パネルと 56 個の連結 要素で構成された CLT シェルは図 3 に示寸通りである。

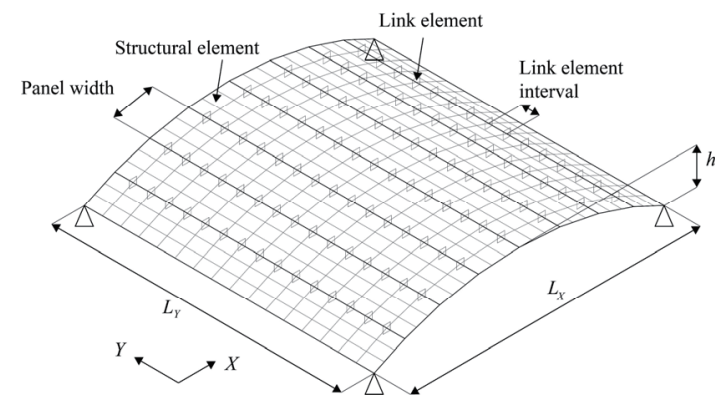

Fig. 3 Numerical model.

本論文では CLT パネルは等幅とする。連結要素の軸方向を $x$ 方 向, 面内せん断方向を $y$ 方向, 面外せん断方向を $z$ 方向として表す (図 2)。連結要素は, 面内軸ば祇剛性 $D_{x}$, 面内せん断ばね剛性 $D_{y}$, 面外せん断ばね剛性 $D_{z}$ および母線方向まわりの回転ばね剛性 $R_{v}$ を並列した 4 つのばね要素（図 2）で構成する。CLT パネルには, 面内力 (膜力および面内せん断力), 面外力 (曲げモーメント, ねじ りモーメントおよび面外せん断力）が生じる。

本論文では, 有限要素法による線形静的解析を行う。構造解析に は OpenSees ${ }^{22}$ を使用する。CLT パネルは, 四角形シェル要素
（ShellMITC4）で離散化する。S60-5-5 を想定し，板厚 150 mm（ラ ミナ厚 $30 \mathrm{~mm}$ ) とする。材料特性は直交異方弾性体を仮定し，ラミ ナの繊維方向弾性係数を $6000 \mathrm{~N} / \mathrm{mm}^{2}$ とする（表 1)。CLT パネル の強軸方向はアーチ方向と一致させる。一般に, CLT パネルは面内・ 面外方向で異なる弾性係数を持つが，本論文では簡単のため，相乗 平均值を用いる。ポアソン比は既往研究 3 に基づき 0.3 とする。境 界条件は四隅をピン支持とする。外力は自重（単位体積重量 5.0 $\left.\mathrm{kN} / \mathrm{m}^{3}\right)$ の夕を考慮し, 負担面積に応じて各節点に集中荷重として 載荷する。

Table 1 Material properties of CLT panel (S60-5-5).

\begin{tabular}{|c|c|c|c|c|c|}
\hline & \multicolumn{2}{|c|}{$\begin{array}{l}\text { Modulus of } \\
\text { elasticity } \\
E\left(\mathrm{~N} / \mathrm{mm}^{2}\right)\end{array}$} & \multicolumn{2}{|c|}{$\begin{array}{c}\text { Modulus of shear } \\
\text { elasticity } \\
G\left(\mathrm{~N} / \mathrm{mm}^{2}\right) \\
\end{array}$} & \multirow{2}{*}{$\begin{array}{l}\text { Poisson's } \\
\text { ratio }\end{array}$} \\
\hline & In-plane & $\begin{array}{l}\text { Out-of- } \\
\text { plane }\end{array}$ & $\begin{array}{c}\text { In- } \\
\text { plane }\end{array}$ & $\begin{array}{l}\text { Out-of- } \\
\text { plane }\end{array}$ & \\
\hline $\begin{array}{l}\text { Strong } \\
\text { axis }\end{array}$ & 3,600 & 4,752 & \multirow{2}{*}{500} & 54.5 & \multirow{2}{*}{0.3} \\
\hline $\begin{array}{l}\text { Weak } \\
\text { axis }\end{array}$ & 2,400 & 1,248 & & 27.2 & \\
\hline
\end{tabular}

\section{2. 接合部の構成とモデル化}

既報 6)で詳細に説明されているため，簡潔に記す。面内せん断力 および面外せん断力は，文献1)に記された鋼板添え板ビス接合 16,17)

（図 4）およびビス接合 18）（図 5）を用いて伝達させる。面外せん 断方向では 1 箇所あたり 4 対で接合する。

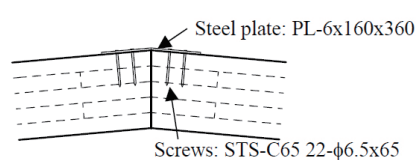

Fig. 4 In-plane shear connection.

\section{Fig. 5 Out-of-plane shear} connection.
曲げモーメントは, CLT の圧縮力（負担幅あたりの繊維方向およ び繊維直交方向のめり込み剛性を考慮 $\left.{ }^{199}\right)$ とラグスクリューボルト (以下 LSB, 図 6)の引張力を用いて伝達させる ${ }^{6)}$ 。軸方向力は, CLT の支圧（圧縮）または LSB（引張）で伝達させる。

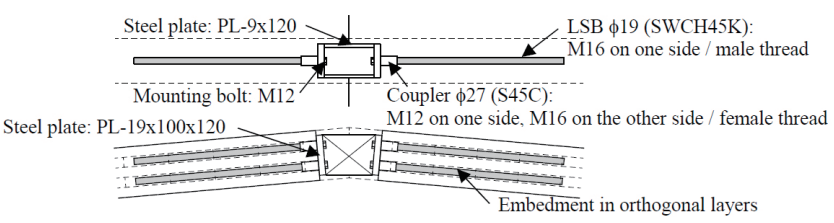

Fig. 6 Moment connection

(Top: horizontal section, Bottom: vertical section) ${ }^{4}$.

連結要素は, 部材長 0 のばね要素（Two Node Link Element）で モデル化する。面内せん断剛性および面外せん断剛性は先行研究 1618)に基づき設定する。

軸方向は，圧縮と引張で剛性の異なる非線形ばねを用いる。圧縮 
剛性は Elastic No Tension Material を用い, 引張力下で 0, 圧縮力 下で $D_{x \mathrm{C}}$ とする。引張剛性は Elastic uniaxial material で $D_{x \mathrm{~T}}$ とす る。軸方向のばね剛性 $D_{x}$ は, これらを重社合わせる。圧縮剛性 $D_{x \mathrm{C}}$ は相互の CLT パネルのめり込み剛性の直列和として次式により表 す。

$$
D_{x \mathrm{C}}=\left(\Sigma k_{/ /} \cdot A_{\mathrm{ply}}+\Sigma k_{\perp} \cdot A_{\mathrm{ply}}\right) / 2 \cdot \cos \phi
$$

ここで， $k_{/ /}$および $k_{\perp}$ はそれぞれ繊維平行方向層のめり込み剛性と 纎維直交方向層のめり込み剛性を表す。これらはラミナの繊維方向 弾性係数 $E_{/ /}\left(=6000 \mathrm{~N} / \mathrm{mm}^{2}\right)$ とラミナ厚さ $t(=30 \mathrm{~mm})$ を用いて $k_{/ /}=E_{/ /} /(31.6+10.9 t)$ および $k_{\perp}=E_{/ /} /\{3.4(31.6+10.9 t)\}$ と表す 19$) 。$ $A_{\mathrm{ply}}$ は各層（プライ）の負担幅あたりの断面積を表す。負担幅は 0.5 $\mathrm{m}$ (端部 $0.25 \mathrm{~m}$ ) とする。これらの式は丸鋼のめり込みを対象とし ている ${ }^{19)}$ 。圧縮剛性の評価方法に関する精度検証は今後の課題であ るが，これらの違いが架構全体の特性に著しい影響を生じさせるも のではない6)。 $\phi$ はパネル傾斜角（図 7）を表す。本論文では CLT パネル間の傾斜角は極めて小さく, $\cos \phi=1$ と仮定する。なお, 連結 要素が配置されないパネル境界部も圧縮力で応力伝達することを考 慮し, Elastic No Tension Material を用い, 引張力下で 0, 圧縮力 下で $D_{x C}$ となるばね要素を配置する。

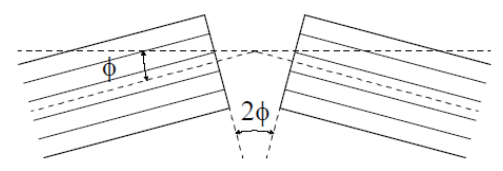

Fig. 7 Tilt angle $\phi$ of CLT panel joint.

引張剛性 $D_{x \mathrm{~T}}$ は片側 $n_{\mathrm{LSB}}$ 本配置された LSB の引き抜き剛性 $K_{\mathrm{LSB}}$, 端部鋼板（PL-19）の曲げ岡性 $K_{\mathrm{S}}$ および中央部鋼板（PL-9）の引張 剛性 $K_{\mathrm{SS}}$ で構成される（図 8)。本論文では $n_{\mathrm{LSB}}=2$ とする。LSB1 本 あたりの軸剛性 $K_{\mathrm{LSB}-\mathrm{S}}$ は次式による。

$$
K_{\mathrm{LSB}-\mathrm{S}}=K_{\mathrm{LSB}} \cdot K_{\mathrm{S}} /\left(K_{\mathrm{LSB}}+K_{\mathrm{S}}\right) \cdot \cos \phi
$$

片側に $n_{\mathrm{LSB}}$ 本配置された LSB は並列ばねで表すことができ, 剛性は $n_{\mathrm{LSB}} \cdot K_{\mathrm{LSB}-\mathrm{S}}$ となる。 $K_{\mathrm{SS}}$ による軸方向変位は微小であるため, 1 対 の並列ばねの直列和として引張剛性 $D_{x \mathrm{~T}}$ を次のように表す。

$$
D_{x \mathrm{~T}}=n_{\mathrm{LSB}} \cdot K_{\mathrm{LSB}} \cdot K_{\mathrm{S}} /\left\{2\left(K_{\mathrm{LSB}}+K_{\mathrm{S}}\right)\right\}
$$

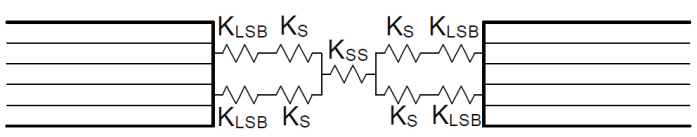

Fig. 8 Composition of axial stiffness in tension.

母線方向の回転剛性 $R_{y}$ は Elastic uniaxial material で定義する。 回転剛性は次式のように表すことができる。

$$
R_{y}=K_{\mathrm{RT}}\left(D-d_{\mathrm{t}}-x_{\mathrm{n}}\right)^{2}+K_{\mathrm{RC}}\left(x_{\mathrm{n}}-d_{\mathrm{c}}\right)^{2}
$$

ここで, $D$ はパネル厚, $d_{\mathrm{t}}$ は引張縁から LSB 中心までの距離, $d_{\mathrm{c}}$ は圧縮縁から圧縮側ラミナ中心までの距離を表す。本論文では $D$ $=150 \mathrm{~mm}, d_{\mathrm{t}}=45 \mathrm{~mm}, d_{\mathrm{c}}=15 \mathrm{~mm}$ とする。 $x_{\mathrm{n}}$ は圧縮縁から中立軸 までの距離を表す。また, 引張側軸剛性 $K_{\mathrm{RT}}$ と圧縮側軸剛性 $K_{\mathrm{RC}}$ は式
（5)による。中立軸 $x_{\mathrm{n}}$ は式(6)のように表すことができる。

$$
\begin{gathered}
K_{\mathrm{RT}}=D_{x, T} / n_{L S B}, K_{\mathrm{RC}}=k_{/ /} \cdot b \cdot t / 2 \\
x_{n}=\left\{K_{\mathrm{RT}}\left(D-d_{\mathrm{t}}\right)+K_{\mathrm{RC}} d_{\mathrm{c}}\right\} /\left(K_{\mathrm{RT}}+K_{\mathrm{RC}}\right)
\end{gathered}
$$

ここで, $b$ は圧縮側の平行層ラミナの負担幅を表す。本論文では $b$ $=1000 \mathrm{~mm}$ とする。 $1 \mathrm{~m}$ 間隔で配置された連結要素のばね剛性を表 2 に示す。

Table 2 Spring stiffness of joint element in unit length.

\begin{tabular}{c|c|c|c|c}
\hline \multicolumn{2}{c|}{$D_{x}(\mathrm{kN} / \mathrm{mm})$} & \multirow{2}{*}{$\begin{array}{c}D_{y} \\
(\mathrm{kN} / \mathrm{mm})\end{array}$} & $\begin{array}{c}D_{z} \\
(\mathrm{kN} / \mathrm{mm})\end{array}$ & $\begin{array}{c}R_{y} \\
(\mathrm{kNm} / \mathrm{rad})\end{array}$ \\
\hline Comp. & Tens. & 14.8 & 14.8 & 901 \\
\hline 901 & 105 & 7.30 &
\end{tabular}

\section{3. 最適化問題の定式化}

総数 $n$ の連結要素をパネル連結部に配置する。総数を軸方向毎で $n_{i}(i=x, y, z)$ と表す。 $j$ 番目の連結要素における軸剛性 (引張), 面内 せん断剛性，面外せん断岡性および回転剛性をそれぞれ $D_{x \mathrm{~T} j}, D_{y j}$, $D_{z j}$ および $R_{y j}$ とする。各連結要素, 各方向の剛性に対する重み付け パラメータを $\rho_{i j} \in\left[0, \beta_{i}\right]$ とする。 $\beta_{i}$ は方向毎のパラメータの上限值を 表す。初期形状 (以下, 初期状態) では全ての連結要素において $\rho_{i j}=1$ とする。パラメータの合計を方向毎で集約すれば，初期形状では $\Sigma \rho_{i j}=n_{i}$ となる。本論文では $\rho_{i j}$ を設計変数とし, 最適化により連結 要素の構成を求める。 $\rho_{i j}=0$ の時, 当該䇢所の連結要素の剛性は 0 となり，接合具は配置しないことを表す。一方， $\rho_{i j}=\beta_{i}$ の時， $\beta_{i}$ 倍した剛性を持つ接合部を配置する。本論文では， $\rho_{i j}$ を次式のよ うに評価し，非整数值で分布することを防ぐ ${ }^{20)}$ 。

$$
\bar{\rho}_{i j}=\left[\rho_{i j}\right]+\left(\rho_{i j}-\left[\rho_{i j}\right]\right)^{\alpha_{i}}
$$

ここで， $\alpha_{i}$ は方向毎のペナルティパラメータを表し， $\alpha_{i} \geq 1.0$ とす る。 $\left[\rho_{i j}\right]$ は $\rho_{i j}$ の整数部分を表す。 $\alpha_{i}=1,4, \beta_{i}=2$ における $\rho_{i j}$ と $\bar{\rho}_{i j}$ の関係を図 9 に示す。

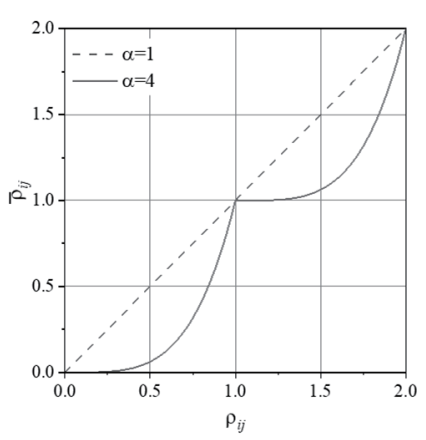

Fig. 9 Penalization of weight parameter $\rho_{i j}\left(\alpha_{i}=1,4, \beta_{i}=2\right)$.

最適化過程における軸剛性 (引張), 面内せん断剛性および面外せ ん断剛性をそれぞれ $\bar{D}_{x \mathrm{~T} j}, \bar{D}_{y j}$ および $\bar{D}_{z j}$ とする。これらは初期状態 の剛性に重み付けパラメータ $\bar{\rho}_{i j}$ を乗じ, 式(8)のように表す。

$$
\begin{aligned}
& \bar{D}_{x \mathrm{~T} j}=\bar{\rho}_{x j} \cdot D_{x \mathrm{~T} j} \\
& \bar{D}_{y j}=\bar{\rho}_{y j} \cdot D_{y j} \\
& \bar{D}_{z j}=\bar{\rho}_{z j} \cdot D_{z j}
\end{aligned}
$$


次に最適化過程における回転剛性を示す。まず， $\bar{D}_{x \mathrm{Tj}}$ を用いて $j$ 番目の連結要素の引張側軸剛性 $\bar{K}_{\mathrm{RT} j}$ と中立軸の位置 $\bar{x}_{n}$ を式(9), (10)のように表す。

$$
\begin{gathered}
\bar{K}_{\mathrm{RT} j}=\bar{\rho}_{x j} \cdot \bar{D}_{x \mathrm{~T} j} / n_{L S B} \\
\bar{x}_{n}=\left\{\bar{K}_{\mathrm{RT} j}\left(D-d_{\mathrm{t}}\right)+K_{\mathrm{RC} j} d_{\mathrm{c}}\right\} /\left(\bar{K}_{\mathrm{RT} j}+K_{\mathrm{RC} j}\right)
\end{gathered}
$$

本論文では, 簡単のため, 式(10)内 $K_{\mathrm{RC}}$ における圧縮側の平行層 ミナの負担幅 $b$ は隣接する重み付けパラメータの有無に関わらず, 一定 $(1 \mathrm{~m})$ とする。これらを用い, 最適化過程の回転剛性 $\overline{R_{y j}}$ を式(11) のように表す。

$$
R_{y}=\bar{K}_{\mathrm{RT} j}\left(D-d_{\mathrm{t}}-\bar{x}_{\mathrm{n}}\right)^{2}+\bar{K}_{\mathrm{RCj}}\left(\bar{x}_{\mathrm{n}}-d_{\mathrm{c}}\right)^{2}
$$

本論文では, CLT シェルの弾性ひずみエネルギーを目的関数とす る。設計変数である重み付けパラメータ $\rho_{i j}$ を方向毎, 連結要素数 分集めたベクトルを $\boldsymbol{\rho}=\left(\boldsymbol{\rho}_{x}^{\top}, \boldsymbol{\rho}_{y}{ }^{\top}, \boldsymbol{\rho}_{z}^{\top}\right)^{\top}$ とする。最適化問題は次式の ように表すことができる。

$$
\begin{aligned}
& \text { minimize } \quad f(\boldsymbol{\rho})=\frac{1}{2} \mathbf{d}(\mathbf{\rho})^{\top} \mathbf{K}(\boldsymbol{\rho}) \mathbf{d}(\mathbf{\rho})=\frac{1}{2} \mathbf{d}(\boldsymbol{\rho})^{\top} \mathbf{F} \\
& \Sigma \rho_{i j} \leq \bar{n}_{i} \\
& \text { subject to } \\
& (i=x, y, z j=1,2, \cdots, n)
\end{aligned}
$$

ここで， $\mathbf{d} ， \mathbf{K}$ および $\mathbf{F}$ はそれぞれ節点変位べクトル，剛性マト リクスおよび外力ベクトルを表す。 $\bar{n}_{i}(i=x, y, z)$ は各方向に集約した $\rho_{i j}$ の総和の上限值を表す。式(12)の制約条件は, 最適化で割り当て る重み付けパラメータの投入量を制限している。また， $\bar{n}_{i} / n_{i}$ は SIMP 法 ${ }^{20)}$ の体積分率に相当すると考えることができる。

最適化問題の解法は逐次二次計画法 (以下 $\mathrm{SQP}$ ) とする。SQP で は SciPyの最適化ライブラリを用い, SLSQP ${ }^{21)}$ を指定する。最適化 の感度係数は差分近似とする。

\section{4. 数値解析例}

\section{1. 例題 1 (連結要素の配置計画)}

ひずみエネルギーが最小となる連結要素の配置を提案手法により 求める。図 10 に示すように, 初期状態における連結要素を $0.5 \mathrm{~m}$ ピ ッチで配置する。総数は $\left(n_{x}, n_{y}, n_{z}\right)=(105,105,105)$ となる。最適解の有 効性を確認するため, 連結要素を $1 \mathrm{~m}$ 間隔で配置した基準モデル (Ref. Model, 図 3) と比較を行う。Ref. model における連結要素の総 数は $\left(n_{x}, n_{y}, n_{z}\right)=(56,56,56)$ である。本例題では, ペナルティパラメ 一タに応じて 2 つのケースに分けて最適化を行う。Case 1 は $\alpha_{i}=1$, Case 2 は $\alpha_{i}=4$ とする。両ケースとも $\beta_{i}=1, \bar{n}_{i}=56$ とする。本例 は, Ref. model と同程度の接合具の数量で合理的な連結要素の配置 を求めることを意図している。

初期值をランダムに変更し, 10 回の最適化を行った。Ref.model 之最適解の変位 (最大変位 $d_{\max }$, 中央変位 $d_{\mathrm{c}}$ ) および目的関数值 $f(\boldsymbol{\rho})$ を表 3 に示す。Case 1 では目的関数の最大值は $251 \mathrm{Nm}$, 最小值は $249 \mathrm{Nm}$ ，平均值は $249 \mathrm{Nm}$ となった。Case 2 はそれぞれ $280 \mathrm{Nm}$ ， $258 \mathrm{Nm}, 265 \mathrm{Nm}$ となった。最大変位 $d_{\max }$ はシェル裾部の中央 $(X=0,8, Y=4)$ で発生している。表 3 を見ると, 最適解では Ref.

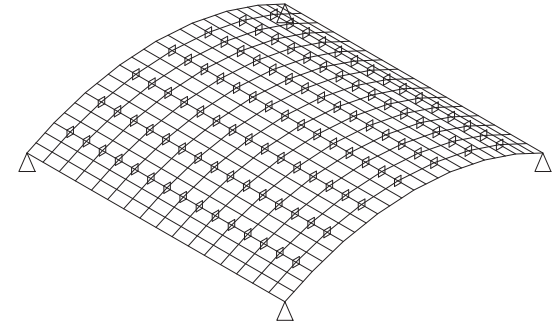

Fig. 10 Initial model $\left(n_{x}, n_{y}, n_{z}\right)=(105,105,105)$.

Table 3 Values of displacement and objective function.

\begin{tabular}{c|c|c|c}
\hline & $d_{\max }(\mathrm{mm})$ & $d_{\mathrm{c}}(\mathrm{mm})$ & $f(\boldsymbol{\rho})(\mathrm{Nm})$ \\
\hline Ref. Model & 18.1 & 6.64 & 292 \\
\hline Case1 & 15.1 & 5.62 & 249 \\
\hline Case2 & 16.6 & 5.79 & 258 \\
\hline
\end{tabular}

model と比べ, ひずみエネルギーは約 12～15\%減少している。また， 最大変位および中央部変位は約 8〜 15\%減少している。

Ref. model と最適解（Case 1) における主応力図と面外せん断力 図を図 11,13 および 15 にそれぞれ示す。各応力図は円筒シェルの $1 / 4$ 領域 $(0 \leq X \leq 4,4 \leq Y \leq 8)$ を示している。各応力図で赤色は圧縮力 または正曲げ（上端面圧縮）を，青色は引張力または負曲げ（上端 面引張）を表す。面外せん断力は要素の最大值を基準とし，值に応 じてカラーマップで示している。この他, 図中のマはパネル継目位 置を, ○は支点を表す。目的関数が最小值となる最適解の重み付け パラメータの分布性状を図 12,14 および 16 にそれぞれ示す。メッ シュは CLT パネルの有限要素を, 隅部の四角形は支持点を表す。 各連結要素を丸で表し, 分布性状は最大值を 1.0 としてグレースケ 一ルで表示している。 $F_{x \max }, F_{y \max }, F_{z \max }$ および $F_{R \max }$ は連結要素の 4 方向 (軸 (圧縮・引張), 面内せん断, 面外せん断, 母線方向まわ りの回転) で生じる応力の絶対值の最大值を示している。Ref. model では, $F_{x \max }=93.0 \mathrm{kN}, F_{y \max }=6.29 \mathrm{kN}, F_{\text {zmax }}=0.793 \mathrm{kN}, F_{R \max }=$ $0.424 \mathrm{kNm}$ となった。

図 11,12 に注目すると，いずれも面外曲げモーメントは最下段パ ネルにおける母線方向の正曲げが最も大きい。中央付近では連結部 の負曲げによる応力伝達が確認できる。最適化によりシェル中央部 の曲げ剛性が重み付けされ，中央付近の負曲げモーメントが増加す る。一方，最下段パネル中央で母線方向に生じていた最大曲げモー メントが減少している。パネル内の連結要素周辺で過大な応力は生 じていない。図 11 と図 12 の比較から, 連結要素の曲げ剛性は母線 軸周りの曲げ応力分布に対応して対角線状に重み付けされる傾向が みられる。次に，図 13,14 を見ると，面内せん断剛性は，最下段か ら 3 段目までの連結部が重み付けされている。特に円筒軸方向では 支点付近に重み付けされる傾向がみられる。これは図 14 における 面内力の伝達経路（支点から支点へアーチ状に伝達）に対応してお り, 各パネルの面内曲げモーメントによる忘力伝達機構が形成され ていることがわかる。面内主応力に着目すると, 最適解では最下段 パネルに生じる応力が Ref.model と比較して減少している。 


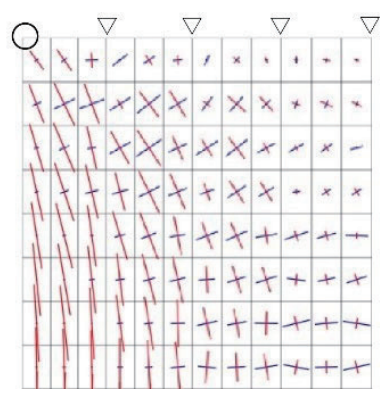

$M_{\max }=1.19 \mathrm{kNm} / \mathrm{m}$,

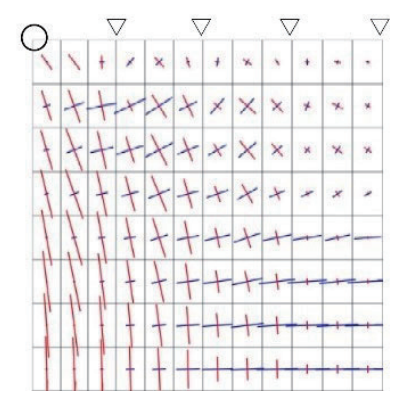

$M_{\max }=0.984 \mathrm{kNm} / \mathrm{m}$,

$M_{\min }=-0.721 \mathrm{kNm} / \mathrm{m}$

Fig. 11 Out-of-plane principal stress

(Left: Ref. Model, Right: Optimal sol. of Case 1).

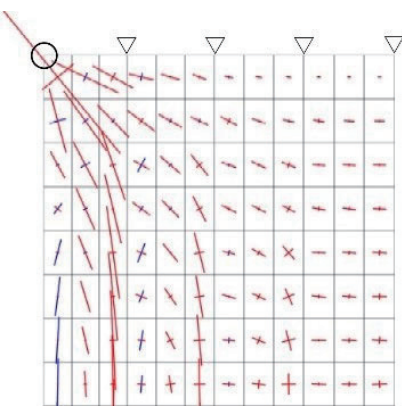

$$
\begin{array}{ll}
N_{\max }=28.6 \mathrm{kN} / \mathrm{m}, & N_{\max }=27.1 \mathrm{kN} / \mathrm{m}, \\
N_{\min }=-112 \mathrm{kN} / \mathrm{m} & N_{\min }=-108 \mathrm{kN} / \mathrm{m}
\end{array}
$$

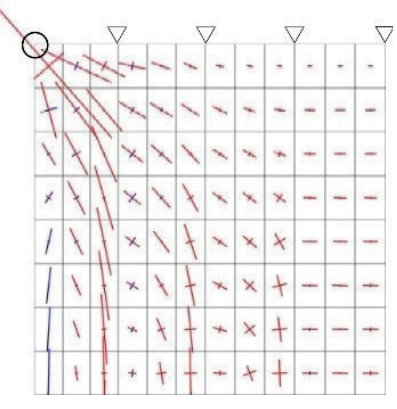

Fig. 13 In plane principal stress (Left: Ref. Model, Right: Optimal sol. of Case 1).
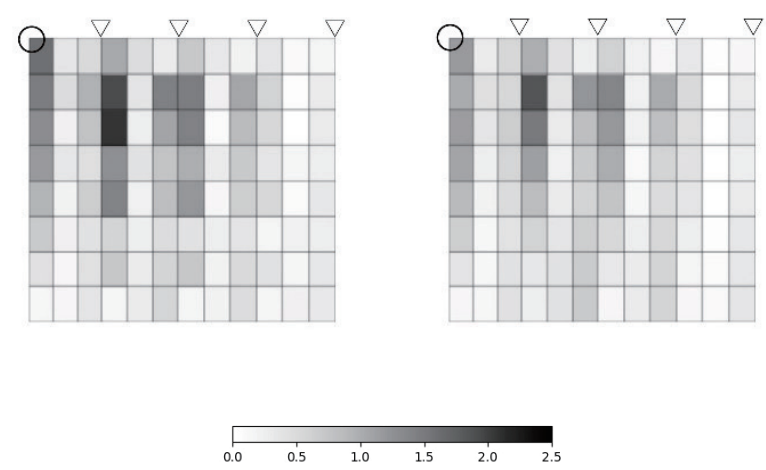

$$
V_{\max }=2.07 \mathrm{kN} / \mathrm{m}
$$

Fig. 15 Out-of-plane shear stress (Left: Ref. Model, Right: Optimal sol. of Case 1).

アーチ方向でパネルが適切に連結し, 重ね梁のように複数部材を使 った効率的な応力伝達の効果が高められたといえる。この他, 面外 せん断剛性は応力状態に応じて, 端部で密に, 中央部で疎に分布し ている。最下段のパネル接合部における面外せん断力を抑えつつ, アーチ自由縁の剛性を向上させるように最適化されている。

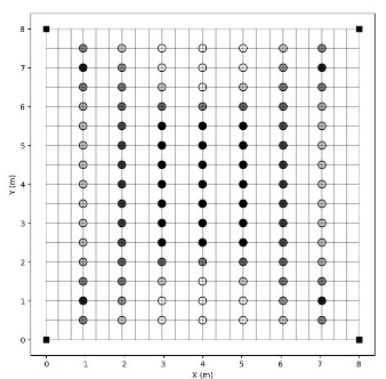

$$
\begin{array}{cc}
F_{x \max }=73.1 \mathrm{kN} & F_{x \max }=85.8 \mathrm{kN} \\
F_{R \max }=0.392 \mathrm{kNm} & F_{R \max }=0.483 \mathrm{kNm}
\end{array}
$$

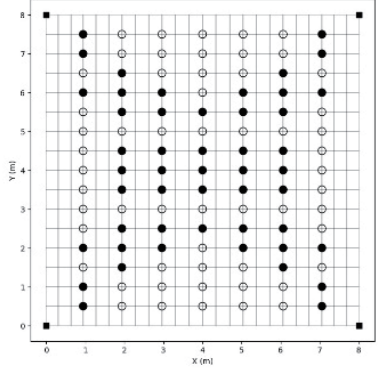

Fig. 12 Distribution of weight parameter $\rho_{x j}$ (Left: Optimal sol. of Case 1, Right: Optimal sol. of Case 2).

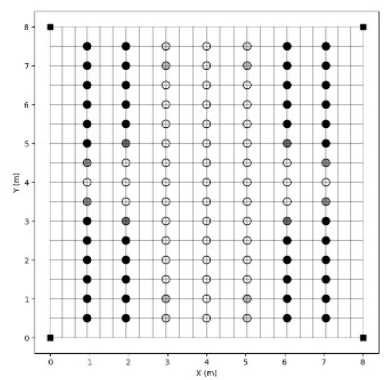

$F_{\text {ymax }}=4.77 \mathrm{kNm}$

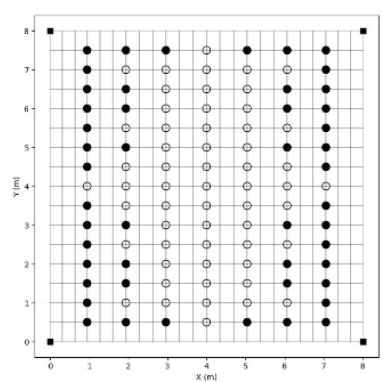

$F_{\text {ymax }}=4.77 \mathrm{kNm}$
Fig. 14 Distribution of weight parameter $\rho_{y j}$ (Left: Optimal sol. of Case 1, Right: Optimal sol. of Case 2).
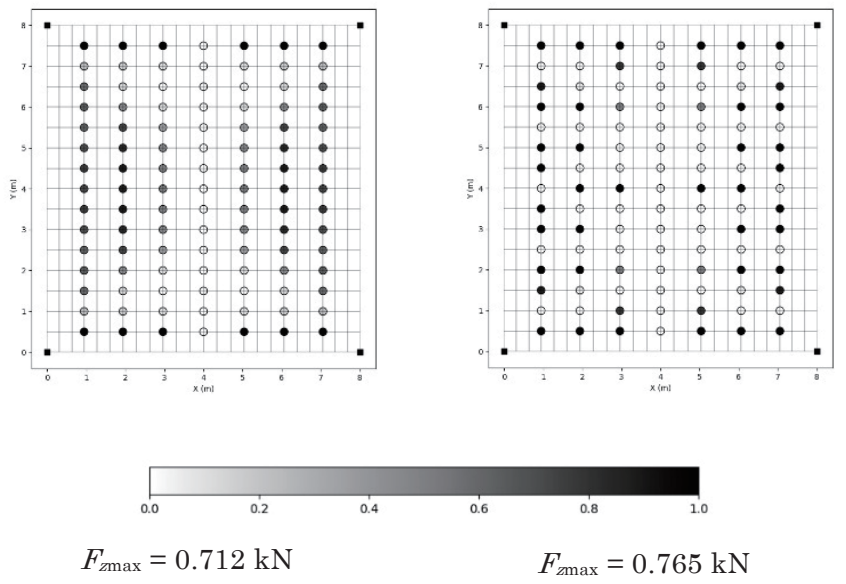

Fig. 16 Distribution of weight parameter $\rho_{z j}$ (Left: Optimal sol. of Case 1, Right: Optimal sol. of Case 2).

4. 2. 例題 2（配置制約下における連結要素剛性の重み付け計画） 実務上，施工性を考慮して連結要素を均等に配置することが望ま しい。また，各連結要素のビス本数を増減させることにより，等間 隔に配置された連結要素の剛性分布性状を把握することが有用であ る。例題 1 で示した配置（特にCase 2) は, 同じ剛性の接合具で構 
成できる利点がある。一方, 接合具が過度に近接すると物理的に収 まらない場合が起こり得る。

ここでは, 収まりや施工性を踏まえ, 母線方向の配置間隔を $1 \mathrm{~m}$ で制限して最適化を行う。初期状態として Ref. model を採用する。 総数は $\left(n_{x}, n_{y}, n_{z}\right)=(56,56,56)$ となる。 $\rho_{i j}$ の総和の上限值は $\bar{n}_{i}=56$ とする。本例題は $\alpha_{i}$ および $\beta_{i}$ の值に応じて 4 つのケースに 分けて最適化を行う。各ケースにおける $\alpha_{i}$ および $\beta_{i}$ を表 4 に示す。 本例題は例題 1 と異なり, いずれのケースも $\beta \geq 1$ とする。すなわち, 初期状態よりも各連結要素の剛性が増加することを許容する。また, 例題 1 と同様, 各方向の剛性の総和は一定とし, 不要な連結要素は 低減・削除するように最適化を行う。Case 3 は, 全ての方向で $\alpha_{i}=1$ とし, 非整数值の解を許容する。Case 4 は $x$ 方向（軸・回転剛性） の $\alpha_{x}=4$ とし，一律に $\alpha_{i}=4$ としたケース（Case 5）の結果と比較す る。

面内・面外せん断方向の剛性はビス本数の増減により連続值で調 整できる。一方, 軸（引張）・曲げ剛性で用いる LSB は 1 本あたり の剛性・耐力が大きいため, 極力離散值で最適化できることが望ま しい。Case 6 は $\beta_{x}$ の上限を 1 以下に制限し, 全方向にペナルティパ ラメータを課し, 軸 (引張)・回転剛性の増加を制限した場合に得ら れる解の特徵を確認する。その他の解析条件, 最適化パラメータは 全て例題 1 と同様である。

Table 4 Parameters $\alpha_{i}$ and $\beta_{i}$ in Numerical example 2.

\begin{tabular}{c|c|c|c|c|c|c}
\hline & $\alpha_{x}$ & $\alpha_{y}$ & $\alpha_{z}$ & $\beta_{x}$ & $\beta_{y}$ & $\beta_{z}$ \\
\hline Case 3 & \multicolumn{3}{|c|}{1} & \multicolumn{3}{|c}{} \\
\cline { 1 - 3 } Case 4 & 4 & 1 & 1 & & 2 \\
Case 5 & \multicolumn{3}{|c|}{4} & & 2 & 2 \\
\hline Case 6 & \multicolumn{3}{|c|}{4} & 1 & 2 & \\
\hline
\end{tabular}

例題 1 と同様, 全てのケースで初期值をランダムに変更し, 10 回 の最適化を行った。各ケースで目的関数が最小值となる時の最大変 位 $d_{\max }$, 中央部変位 $d_{\mathrm{c}}$ および目的関数值 $f(\boldsymbol{\rho})$ を表 5 に示す。最大変 位 $d_{\max }$ の発生位置は例題 1 と同様である。Ref. model と比べ, いず れの最適解においてもひずみエネルギーは約 $12 \%$, 最大変位は約 4 $\sim 7 \%$, 中央部変位は約 15～18\%減少している。概衫 Case 2 と同程 度減少していると考えられる。

Case 3〜Case 6 の最適解における重み付けパラメータの分布性 状を図 17〜20 に示す。重み付けパラメータのヒストグラムを図 21 に示す。横軸は重み付けパラメータの值 (0.1 刻み) を, 縦軸は該当 するパラメータの数を表す。

図 17 (a), 18 (a)および図 21 (a)をみると， $\rho_{x j}$ に関して $\alpha_{x}=4$ のペ ナルティパラメータを課すことにより, 効果的に非整数值の発生を 抑制できていることがわかる。例題 1 と同様に対角線方向に沿い, 中央付近で重み付けされている。図 18 (a)〜20 (a)も併せてみると, 同様の傾向が確認できる。Case 6 はアーチ自由縁を除き, 全て $\rho_{x j}=1$ で分布している。図 17(b)〜20(b)および図 $21(\mathrm{~b})$ を見ると， 最下段連結部の面内せん断剛性が上限まで重み付けされており, 剛 性分布は $\alpha_{y}$ の值に関わらず同様となることが確認できる。この部 分の剛性の重み付けがひずみエネルギーの低減に効果的であるとい える。更に, 図 17(c)-20(c)および図 21 (c)を見ると, 面外せん断剛 性の重み付けパラメータは中央部で小さく, 支点近傍で大きくなる ように最適化されている。 $\alpha_{z}=4$ とすることにより非整数值の発生 を抑制できるが，軸・回転剛性に比べ，重み付けパラメータの值は 分散する傾向にある。ここで, 表 5 において Case 5 と Case 6 を比 べると, Case 5 は中央部の変位は小さいが, 最大変位や目的関数值 はより厳しい制約条件が課された Case 6 よりも僅かに大きい值を 示している。これは全ての方向でペナルティパラメータが課され， 局所解に収束したことが原因と考えられる。 $\alpha_{i} \geq 1$ とする場合，局 所解に収束寸る可能性があることを念頭に置く必要がある。

各ケースにおける最大主応力, 最大面外せん断力の最大值の一覧 を表 6 に, 連結要素で生じる応力 $\left(F_{x \max }, F_{y \max }, F_{\text {zmax }}\right.$ および $\left.F_{R \text { max }}\right)$ の最大值の一覧を表 7 に示す。また, 3 方向の応力（面内せん断, 面外せん断および曲げモーメント）において，重み付けパラメータ $\rho_{i j}=1$ あたりの応力 $\left(F_{y j} / \rho_{y j}, F_{z j} / \rho_{z j}\right.$ および $\left.F_{R j} / \rho_{x j}\right)$ の最大值を 算定し, 表 8 に示寸。表 6 より CLT パネルの面内主応力に着目寸 ると最大值は減少している。これは例題 1 と同様, 最下段から 3 段 目までの面内せん断剛性が重み付けされたことにより立体効果が得 られたことに起因している。面外主応力については負曲げモーメン 卜が増加する一方，正曲げモーメントは減少している。これも例題 1 と同様の傾向である。したがって, 連結要素間隔を制限した条件 下においても合理的な連結要素の構成を得ることができたといえる。 また, 表 7 を見ると, 連結要素の応力は Ref. model と比べて面内せ ん断方向で最大約 $33 \%$, 回転方向で約 12〜21\%増加しているケー スが確認できる。しかしながら，表 8 を見ると，Case6 は $\beta_{x} \leq 1$ の制 約に伴い, 曲げモーメントの減少量は小さく, 面外せん断力は Ref. model より若干増加している。他のケースでは $\rho_{i j}=1$ あたりの応力 は減少している。先行研究 ${ }^{6)}$ を参照すれば $\rho_{i j}=1$ における接合部の 降伏耐力は軸(圧縮・引張), 面内せん断, 面外せん断, 回転方向でそ れぞれ $972 \mathrm{kN}, 164 \mathrm{kN}, 33.0 \mathrm{kN}, 29.6 \mathrm{kN}$ および $7.38 \mathrm{kNm}$ であ り, 存在応力は十分小さな值であることがわかる。以上より, 例題 1,2 とも最適化を用い, 複数方向に剛性を持つ連結要素の配置を効 率よく求めることが示された。

Table 5 Values of displacement and objective function.

\begin{tabular}{c|c|c|c}
\hline & $d_{\max }(\mathrm{mm})$ & $d_{\mathrm{c}}(\mathrm{mm})$ & $f(\boldsymbol{\rho})(\mathrm{Nm})$ \\
\hline Ref. Model & 18.1 & 6.64 & 292 \\
\hline Case 3 & 16.8 & 5.61 & 253 \\
\hline Case 4 & 17.0 & 5.56 & 254 \\
\hline Case 5 & 17.3 & 5.43 & 258 \\
\hline Case 6 & 17.1 & 5.65 & 257 \\
\hline
\end{tabular}




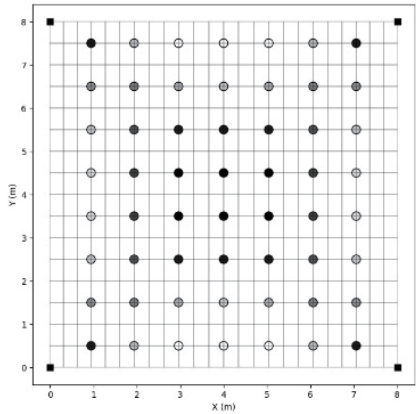

$\mathrm{a}$ : Tensile and bending $\left(\rho_{x j}\right)$

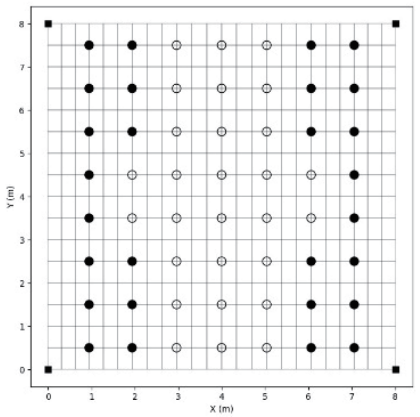

$\mathrm{b}$ : In-plane shear $\left(\rho_{y j}\right)$

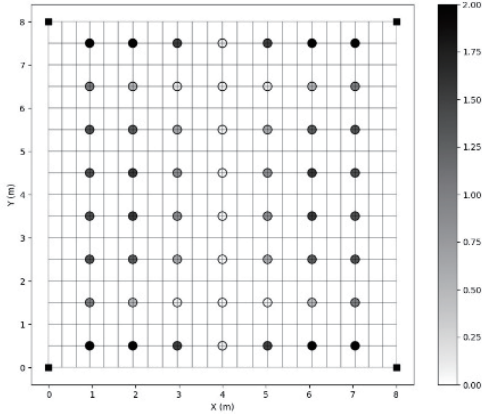

c: Out-of-plane shear $\left(\rho_{z j}\right)$

Fig. 17 Distribution of weight parameter in optimal sol. of Case 3.

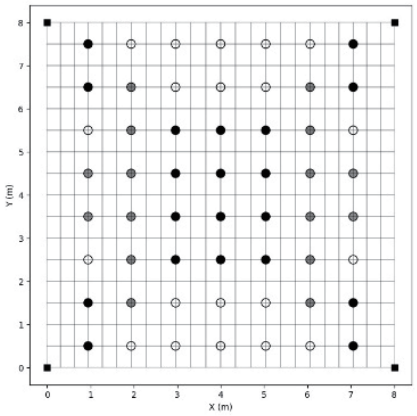

a: Tensile and bending $\left(\rho_{x j}\right)$

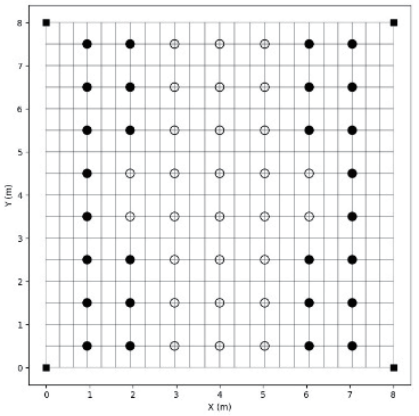

$\mathrm{b}$ : In-plane shear $\left(\rho_{y j}\right)$

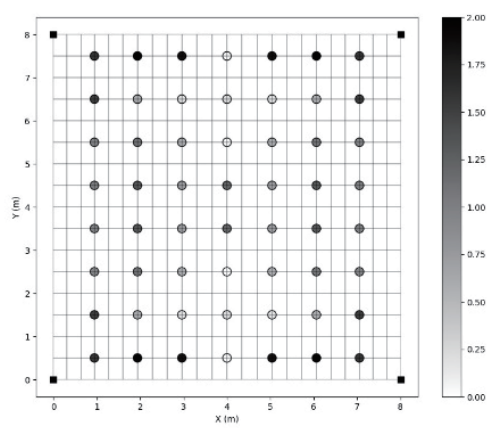

c: Out-of-plane shear $\left(\rho_{z j}\right)$

Fig. 18 Distribution of weight parameter in optimal sol. of Case 4.

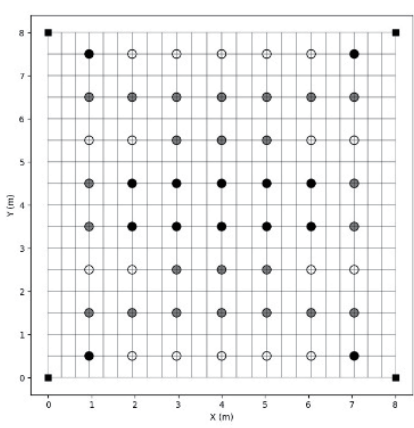

a: Tensile and bending $\left(\rho_{x j}\right)$

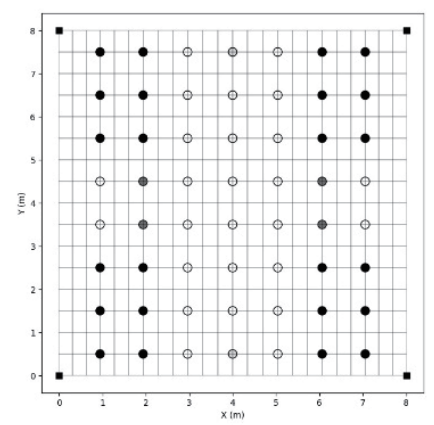

$\mathrm{b}$ : In-plane shear $\left(\rho_{\nu j}\right)$

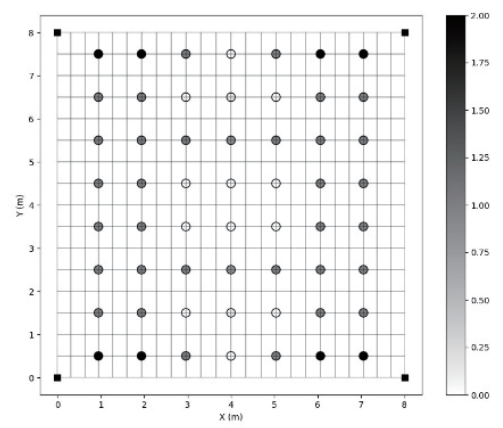

c: Out-of-plane shear $\left(\rho_{z i}\right)$

Fig. 19 Distribution of weight parameter in optimal sol. of Case 5.

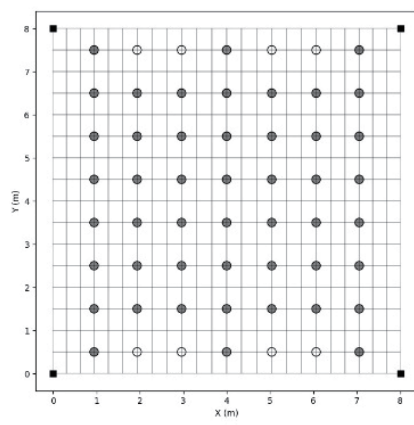

a: Tensile and bending $\left(\rho_{x j}\right)$

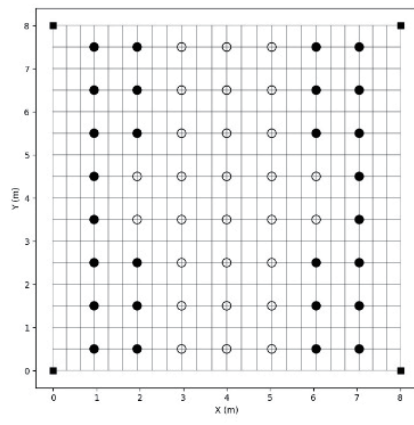

$\mathrm{b}$ : In-plane shear $\left(\rho_{y j}\right)$

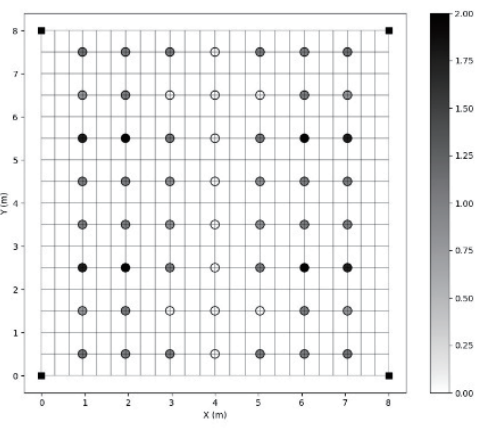

c: Out-of-plane shear $\left(\rho_{z j}\right)$

Fig. 20 Distribution of weight parameter in optimal sol. of Case 6. 


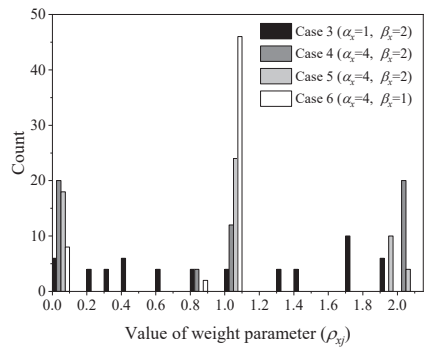

a: Tensile and bending $\left(\rho_{x j}\right)$

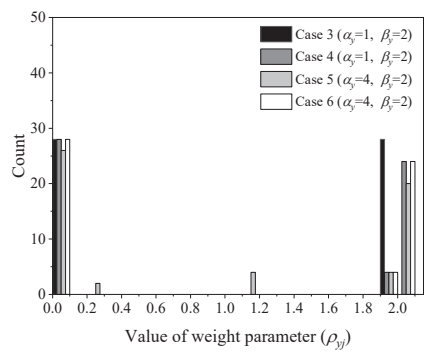

b: In-plane shear $\left(\rho_{v j}\right)$

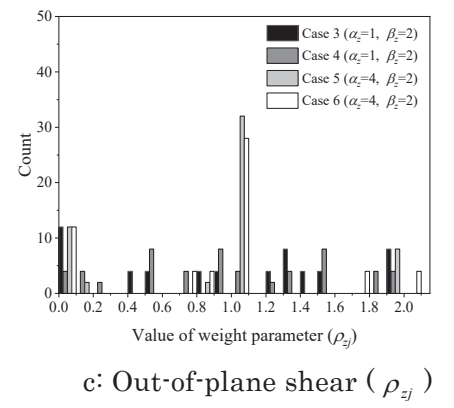

c: Out-of-plane shear $\left(\rho_{z i}\right)$

Fig. 21 Histogram of optimal weight parameter in Case 3-6.

Table 6 Max. principal stress and out-of-plane shear stress in

Ref.model and optimal sol. of Case 3-6 (kN/m, kNm/m).

\begin{tabular}{c|c|c|c|c|c}
\hline & $N_{\max }$ & $N_{\min }$ & $M_{\max }$ & $M_{\min }$ & $V_{\max }$ \\
\hline Ref. Model & 28.6 & -112 & 1.19 & -0.442 & 2.07 \\
\hline Case 3 & 28.2 & -107 & 1.09 & -0.512 & 1.95 \\
\hline Case 4 & 28.4 & -107 & 1.09 & -0.508 & 1.92 \\
\hline Case 5 & 29.3 & -108 & 1.10 & -0.583 & 1.95 \\
\hline Case 6 & 28.6 & -108 & 1.12 & -0.479 & 1.97 \\
\hline
\end{tabular}

Table 8 Max. value of $F_{y j} / \rho_{y j}, F_{z j} / \rho_{z j}$ and $F_{R j} / \rho_{x j}$ in

Ref.model and optimal sol. of Case 3-6 (kN, kNm).

\begin{tabular}{c|c|c|c}
\hline & $F_{v i} / \rho_{v i}$ & $F_{z i} / \rho_{z i}$ & $F_{R i} / \rho_{x i}$ \\
\hline Ref.Model & 6.29 & 0.793 & 0.424 \\
\hline Case 3 & 4.16 & 0.419 & 0.257 \\
\hline Case 4 & 4.16 & 0.496 & 0.317 \\
\hline Case 5 & 4.19 & 0.454 & 0.346 \\
\hline Case 6 & 4.17 & 0.812 & 0.417 \\
\hline
\end{tabular}

\section{5. 結論}

多軸方向に剛性を有する接合具と CLT パネルで構成された円筒 シェルを対象とし, 接合具の最適な構成を探索する方法として, 連 結要素の各方向の剛性に乗じる重み付けパラメータを設計変数とし た最適化手法を提案した。数值解析例を通して重み付けパラメータ と応力分布から解の有効性を確認した。本論文で得られた結論は以 下のように要約される。

[1] 連結要素を各方向に剛性を有するばね要素でモデル化し, 重 み付けパラメータを設計変数, 方向毎の重み付けパラメータ の総和の上限を制約条件, ひずみエネルギーを目的関数とし て定式化した最適化問題を解くことにより, 各方向の剛性分 布を求めることができる。これらを重㸚合わせ, 力学性状に対 応した連結要素の構成を計画することが可能である。

[2] 連結要素の最適な位置関係を探索した例題 1 の最適解と実務 的な寸法で連結要素を等間隔に配列し, 剛性分布も併せて探 索した例題 2 の最適解はいずれも同様の傾向を示している。 実務上, 前者は一定の接合具のみで構成できる利点がある。後 者はディテールの収まりから計画する場合に優位である。

[3] 階段状のペナルティパラメータを設定することにより, 離散 值に近い重み付けパラメータの分布を求めることができる。
Table 7 Max. internal force at boundaries of CLT panels in

Ref.model and optimal sol. of Case 3-6 (kN, kNm).

\begin{tabular}{c|c|c|c|c}
\hline & $F_{x \max }$ & $F_{y \max }$ & $F_{\text {max }}$ & $F_{R \max }$ \\
\hline Ref. Model & 93.0 & 6.29 & 0.793 & 0.424 \\
\hline Case 3 & 90.2 & 8.33 & 0.838 & 0.514 \\
\hline Case 4 & 93.4 & 8.33 & 0.843 & 0.504 \\
\hline Case 5 & 95.2 & 8.39 & 0.862 & 0.474 \\
\hline Case 6 & 95.1 & 8.33 & 0.812 & 0.417 \\
\hline
\end{tabular}

これにより連結要素の配置計画において, 基準とする接合具 を整数倍して設計できるので, 実務上有用である。ただし, 全 ての方向で 1 以上のペナルティパラメータを課す場合は局所 解に収束する可能性があることを念頭に置く必要がある。

[4]ひずみエネルギーの最小化により，面外曲げ応力に対応する ように円筒頂部中央付近から支点位置へ向けて対角線状に曲 げ剛性が重多付けされ，円筒裾部分の変位を抑制している。ま た，最下段から数段までのパネルで重㸚梁のような立体効果 が得られるように, 面内せん断剛性が最適化される。面外せん 断剛性は, 荷重の負担に応じて中央部で小さく, 端部で高くな る。

\section{謝辞}

本研究は公益財団法人日比科学技術財団の研究助成を受けまし た。ここに記して謝意を表します。

\section{参考文献}

1) CLT Design and Construction Manual Editorial Committee: Building design and construction manual using CLT, Japan Housing and Wood Technology Center, 2016.10 (in Japanese).

CLT 設計施工マニュアル編集委員会: 2016 年版 CLT を用いた建築 物の設計施工マニュアル，公益財団法人日本住宅・木材技術センター, 2016. 10.

2) K. Murakami, A. Mimatsu, Y. Esaka, M. Shiozaki, K. Komatsu, M. Murakami: An experimental study on keyed beam design method for two-way flat slab composed of Cross Laminated Timber, AIJ Journal of Technology and Design, Vol. 24, No.57, pp. 607-612, 2018.6 (in Japanese).

村上勝英，三松あずさ，江坂佳賢，塩崎征男，小松賢司，村上雅英：重 衩梁形式の CLT 二方向フラットスラブの設計方法に関する実験的研 究, 日本建築学会技術報告集, 第 24 巻, 第 57 号, pp.607-612, 2018.6.

3) Y. Esaka, K. Murakami, A. Mimatsu, S. Honda, M. Shiozaki, K. Komatsu, M. Murakami, M. Inayama, M. Ida: Development and verification of analytical method using FEM for structural design to 
model out of plane bending behavior of two-way flat slab using CLT, AIJ Journal of Technology and Design, Vol. 26, No.62, pp. 103-108, 2020.2 (in Japanese)

江坂佳賢, 村上勝英, 三松あずさ, 本田貞光, 塩崎征男, 小松賢司, 村 上雅英, 稲山正弘, 井田茉利 : CLT 二方向フラットスラブの設計用面 外曲げ FEM 解析方法の開発と検証，日本建築学会技術報告集，第 26 巻, 第 62 号, pp.103-108, 2020.2.

4) WOOD STRUCTURE PROM INC., Japan Housing and Wood Technology Center (eds.): Report on CLT construction verification support project subsidized by Ministry of Agriculture, Forestry and Fisheries in H30，pp.145-164， 2020.3 (in Japanese).

木構造振興株式会社, 公益財団法人日本住宅・木材技術センター (編)： 平成 30 年度補正林野庁補助事業 CLT 建築実証支援事業報告書, pp.145-164, 2020.3.

5) C. Robeller, N. V. Haaren: Recycleshell: Wood-only Shell Structures Made from Cross-Laminated Timber (CLT) Production Waste, Journal of the International Association for Shell and Spatial Structures, Vol.61, No.2, n.204, pp.125-139, 2020.6.

6) K. Noda, Y. Kanebako: Feasibility study on structural design for arched and interconnected CLT shells, Journal of Structural Engineering, Vol.67B, pp.121-127, 2021.3 (in Japanese). 野田 賢, 金箱温春: 円弧状に連結された CLT シェルの構造設計に関 する基礎的考察，構造工学論文集, Vol.67B, pp.121-127, 2021.3.

7) Y. Hangai: Shape analysis for the creation of structures, SEISAN KENKYU, Vol. 47, No.1, pp.2-9, 1995.1 (in Japanese).

半谷裕彦: 構造物の形態解析と創生, 生産研究, 47 巻 1 号, pp. $2-9$, 1995.1.

8) M. Ohsaki and K. Hayashi, Force density method for simultaneous optimization of geometry and topology of trusses, Struct. Multidisc. Optim., Vol. 56(5), pp. 1157-1168, 2017.

9) T. Kimura, M. Ohsaki, R. Okazaki, Simultaneous optimization of brace locations and cross-sections of beams and columns of steel frames, Journal of Structural and Construction Engineering (Transactions of AIJ), Vol. 83, No. 752, pp.1445-1454, 2018.10 (in Japanese).

木村俊明, 大崎 純, 岡崎 綾, 鋼構造骨組のブレース配置と柱・梁断面 の 同時最適化, 日本建築学会構造系論文集, Vol. 83, No. 752, pp. 1445-1454, 2018.10.

10) M. P. Bendsøe, N. Kikuchi, Generation optimal topologies in structural design using a homogenization method, Comp. Meth. appl. Mech, Engng., Vol. 71, pp.197-224, 1988.

11) D. Fujii, S. Ejima, N. Kikuchi, Topology optimization of compliant mechanisms using the homogenization design method, Journal of Structural and Construction Engineering (Transactions of AIJ), No. 528, pp.99-105, 2000.2 (in Japanese).

藤井大地, 江島 晋, 菊池 昇: 均質化設計法を用いた弾性変形機構の位 相最適化, 日本建築学会構造系論文集, No. 528, pp. 99-105, 2000.2.

12) D. Fujii N. Kikuchi: Topology optimization of composite material using the homogenizatoin design method, Journal of Structural and Construction Engineering (Transactions of AIJ), No. 535, pp. 79-86, 2000.9 (in Japanese).

藤井大地, 菊池 昇: 均質化設計法を用いた複合材料の位相最適化, 日 本建築学会構造系論文集, No. 535, pp. 79-86, 2000.9.

13) S. Matsumoto, Y. Kasuga, D. Fujii, Y. Fujitani: Minimum cost analysis of semi-rigidly connected steel frames considering cost of joints, Journal of Structural and Construction Engineering (Transactions of AIJ), Vol.528, pp.113-119, 2000.2 (in Japanese). 松本慎也, 春日康博, 藤井大地, 藤谷義信 : 接合部のコストを考慮した 半剛接鉄骨骨組の最小コスト解析, 日本建築学会構造系論文集, 第 528 号, pp.113-119, 2000.2 .

14) T. Hagishita, M. Ohsaki: Optimal placement of braces for steel frames with semi-rigid joints by scatter search, Comp. \& Struct., Vol. 86, Issues 21-22, pp.1983-1993, 2008.

15) A. Fukushima, H. Hamada: Structural Computational Morphogenesis of Wooden Single Layer Latticed Shell Simultaneous Optimization for Shape, Member Section and Joint
Stiffness-, Summaries of Technical Papers of Annual Meeting, Architectural Institute of Japan, Structures-I, pp.921-922, 2018.7 (in Japanese).

福島 敦, 浜田英明 : 木造単層格子ラチスシェルの構造形態創生 形状・ 部材断面・接合部剛性の同時最適化, 日本建築学会大会学術講演梗概 集, 構造 I, pp.921-922, 2018.7.

16) WOOD STRUCTURE PROM INC., Japan Housing and Wood Technology Center (eds.): Report on project for verification of structural planning and joint performance of medium and high-rise buildings using CLT panels subsidized by Ministry of Agriculture, Forestry and Fisheries in H23, 2012.3 (in Japanese).

木構造振興株式会社, 公益財団法人日本住宅・木材技術センター (編) : 平成 23 年度林野庁補助事業 CLT パネルを用いた中高層建築物の構 造計画と接合部性能の検証事業報告書, 2012.3.

17) T. Goto, K. Suzuki, Y. Shimizu, Y. Motoi, C. Tsuda, K. Mori, T. Miyake, K. Makimoto: Cross-laminated timber study on seismic performance of structures: Part 3 Joint test, Summaries of Technical Papers of Annual Meeting, Architectural Institute of Japan, Structures-III, pp. 309-310, 2012. 7 (in Japanese).

後藤隆洋, 鈴木 圭, 清水庸介, 安村 基, 津田千尋, 森 清輝, 三宅辰哉, 槌本敬大 : クロス・ラミネイティド・ティンバーによる構造の耐震性能 に関する研究 その 3. 接合部試験, 日本建築学会大会学術講演梗概集, 構造 III, pp.309-310, 2012.7.

18) Japan Housing and Wood Technology Center (ed.): Report on building verification project using CLT and other new products and technologies, pp.95-116, 2015.3 (in Japanese).

公益財団法人日本住宅・木材技術センター（編）：平成 26 年度林野 庁補助事業 CLT 等新たな製品・技術活用建築物実証事業報告書, pp.95-116, 2015.3.

19) AIJ (ed.): AIJ Standard for Structural Design of Timber Structure. 2006.12 (in Japanese).

日本建築学会 (編) : 木質構造設計規準・同解説 -許容応力度・許容而 力設計法-, 2006.12.

20) M. P. Bendsøe: Optimal shape design as a material distribution problem, Structural Optimization, Vol.1, pp.193-202, 1989

21) $\mathrm{AIJ}$ (ed.): Introduction to Design Computing: Python Programming for Generation, Simulation and Optimization of Architectural Form and Function, Koronasya, 2017 (in Japanese). 日本建築学会 (編) : デザイン・コンピューティング入門 Pythonによ る建築の形態と機能の生成・分析・最適化, コロナ社, 2017 .

22) Open System for Earthquake Engineering Simulation (OpenSees), PEERC, UC Berkeley, http://opensees. berkeley.edu/ (accessed 2021.9.4). 


\title{
TOPOLOGY FINDING METHOD OF LINK ELEMENTS FOR CLT SHELLS
}

\author{
Ken NODA*1 and Toshiaki KIMURA*2 \\ ${ }^{*}$ Kanebako Structural Engineers, M.Eng. \\ * 2 Lect., Graduate School of Design and Architecture, Nagoya City Univ., Dr.Eng.
}

Cross Laminated Timber (CLT) is a wood-based component consisting of laminated laminae lined up in the width direction and laminated and bonded so that the fiber directions are orthogonal. When used in slabs, it is a standard approach to use the out-of-plane stiffness of CLT in the major axial direction. Due to the cross-laminating characteristics, designing the slab which allows stress transmitting in two directions is also possible. However, they should be interconnected using appropriate joints, corresponding to the stress transmission between each panel. Additionally, when designing shell structures, the stress transmitting both out-of-plane forces and in-plane forces are needed to be considered simultaneously. Currently, design methods for the CLT shells are not well established. Therefore, some studies have been conducted depending on each design project. The author previously proposed a design approach for arched and interconnected CLT shells. An optimization method is expected to obtain structural rational joint arrangements, which will be useful for structural design.

This paper presents an optimization method of the joint arrangement for shell structures composed of CLT panels. The joining system is modeled as multidirectional link elements consisting of axial, in-plane / out-of-plane shear, and out-of-plane bending stiffness. The values of the stiffness are calculated by multiplying the weight parameters defined as the design variables to the original values which are based on the existing design code and the result of the experimental test. Furthermore, for obtaining the practical topology, the penalty parameter expressed as a step-like power-law function is introduced by multiplying to design variables. An optimization problem is formulated to minimize the strain energy with the constraint condition in terms of the summation of the weight parameter.

It is shown in two numerical examples that the distribution of the weight parameter in each direction is optimized corresponding to the stress state. By multiplying the weight parameter to the original stiffness and superposing them for each direction, the optimal joint arrangement can be obtained. The tendency of the weight parameter distributions of the optimal solutions can be described as follows, (i) For the bending stiffness, according to the out-of-plane bending stress state, the bending stiffness is weighted diagonally from the center to the supports, and the displacement at the bottom of the cylinder is suppressed. (ii) For the distribution of the in-plane shear stiffness, it is close to the bottom and corners tend to be weighted to behave such as a stacked beam. (iii) For the out-of-plane shear stiffness, the distribution of the joint arrangement tends to be sparse in the center; contrary to this, the edges to be dense due to the load-carrying capacity. In the initial state of example 1 , the link elements are located at $0.5 \mathrm{~m}$ pitch, and the weighting upper limit is set to 1 . While, in example $2,1.0 \mathrm{~m}$ pitch is assigned considering practical aspects with the weighting upper limit greater than 1 . As for the structural properties of the optimal solutions, a similar tendency can be found through both numerical examples. In practical design, the optimal solution of example 1 has the advantage in the case of using only a kind of joint for each stiffness, while the optimal solution of example 2 is advantageous in the case of finding the suitable arrangement considering the physical size of the connectors. 